ORIGINAL ARTICLE

\title{
Comparison of Pain and Anxiety Level Induced by Laser vs Rotary Cavity Preparation: An In Vivo Study
}

\author{
Sana Alia ${ }^{1}$, Suleman A Khan ${ }^{2}$, Saumya Navit ${ }^{3}$, Anshul Sharma ${ }^{4}$, Seema Jabeen ${ }^{5}$, Nishi Grover ${ }^{6}$, Saarika Suresh ${ }^{7}$
}

\begin{abstract}
Aim: To evaluate and compare the pain perception, anxiety level, and acceptance of Er,Cr:YSGG laser (2780 nm) with a conventional rotary method during cavity preparation in children.

Materials and methods: In a randomized controlled trial, using split-mouth design thirty 6- to 12-year-old children with 60 carious molars were examined. In one quadrant, cavity was prepared conventionally by airotor while, in the other quadrant, Er,Cr:YSGG laser was used. Anxiety was assessed by measuring pulse rate using a fingertip pulse oximeter, while the pain was measured on the Wong-Baker Faces Pain Rating Scale. After the cavity preparation by both the methods, the child was asked about the preference for future treatment of a carious lesion.

Results: Pulse rate was found significantly higher in the airotor group but no significant difference in pulse rate was found in the laser group when compared to the baseline pulse rate. The mean value of pain in the airotor group was slightly higher than the laser group. Fifty-seven percent of children preferred Er,Cr:YSGG laser for cavity preparation in the future.

Conclusion: During cavity preparation, Er,Cr:YSGG laser comes out to be more effective and acceptable, as it is less anxiety-provoking and may cause less pain when compared with the airotor.

Clinical significance: Er,Cr:YSGG laser helps the children to remain calm during the cavity preparation.

Keywords: Dental anxiety, Pain, Randomized controlled clinical trial.

International Journal of Clinical Pediatric Dentistry (2020): 10.5005/jp-journals-10005-1820
\end{abstract}

\section{INTRODUCTION}

Pain, anxiety, and fear are often accompanied when the conventional method of mechanical cutting is used for the removal of carious dental tissues and to prepare cavities. In dental setup, many stimulants trigger anxiety, such as, sound, sight, smell, and vibration associated with dental handpiece. Thus, it can be a cause for the abstain of dental appointments which may result in the enhancement of caries occurrence and oral diseases. For this reason, the " $4 \mathrm{~S}$ " rule, which is based upon the removal of four of the major primary sensory triggers - sound (drilling), sight (air turbine drill), smell, and sensation (high-frequency vibrations) is used. ${ }^{1-8}$

The idea of substituting the drill with Erbium family lasers helps pediatric dentists in the treatment of the hard and soft tissues of the oral cavity safely and efficiently. The Er,Cr:YSGG laser $(2780 \mathrm{~nm}$ ) has proven to be an effective tool for ablating enamel and dentine. Laser interaction with water at the tissue interface results in a precise cut of hard tissue. It provides higher safety compared to conventional methods in which rotating instruments in a small mouth can damage or hurt soft tissue if the child moves unpredictably. The affinity of the laser beam for carious structures results in minimal removal of sound tooth structure. There is a liability for obtaining an effective ablation without thermal negative effects on underlying tissues. Non-contact mode of laser induces less vibration that ensues increased child cooperativeness. When adequate protocol of isolation is followed, there is no risk of any contamination. The laser noise so-called "popcorn effect", due to the burst of the water molecules inside the cells is responsible for tissue ablation. The popping sound produced by the laser is much more comfortable than the drill noise to the children. ${ }^{9-11}$

Pain is a subjective component, so it is preferable to obtain a response through a child's own perception. The Wong-Baker
${ }^{1-7}$ Department of Pedodontics and Preventive Dentistry, Saraswati Dental College, Lucknow, Uttar Pradesh, India

Corresponding Author: Sana Alia, Department of Pedodontics and Preventive Dentistry, Saraswati Dental College, Lucknow, Uttar Pradesh, India, Phone: +91 7081680079, e-mail: envisagetojannah@ gmail.com

How to cite this article: Alia S, Khan SA, Navit S, et al. Comparison of Pain and Anxiety Level Induced by Laser vs Rotary Cavity Preparation: An In Vivo Study. Int J Clin Pediatr Dent 2020;13(6):590-594.

Source of support: Nil

Conflict of interest: None

Faces Pain Rating Scale has many advantages. It is a self-report instrument that comprises - a row of six representative images (icons) ranging from "No hurt" to "Hurts worst" corresponding to score 0 to 10, respectively. It is easy to administer and the rate does not take too much time to complete and can be used in children and adolescents. Anxiety precipitates many physiological changes in the body, such as, increase in perspiration, blood pressure, heart rate, and pulse rate, which are primarily due to the release of stress hormones in the blood, such as, cortisol, adrenaline, and norepinephrine. The pulse oximeter can be used to record some of these physiological changes. It helps in real-time recording of physiological parameters, such as, blood pressure, pulse rate, and oxygen saturation. ${ }^{12-14}$

In the light of the above-mentioned facts, this study was conducted to evaluate and compare the pain perception, anxiety level, and acceptance of laser with a conventional rotary method for cavity preparation in children.

(c) Jaypee Brothers Medical Publishers. 2020 Open Access This article is distributed under the terms of the Creative Commons Attribution 4.0 International License (https://creativecommons.org/licenses/by-nc/4.0/), which permits unrestricted use, distribution, and non-commercial reproduction in any medium, provided you give appropriate credit to the original author(s) and the source, provide a link to the Creative Commons license, and indicate if changes were made. The Creative Commons Public Domain Dedication waiver (http://creativecommons.org/publicdomain/zero/1.0/) applies to the data made available in this article, unless otherwise stated. 


\section{Materials and Methods}

Thirty patients aged between 6 years and 12 years attending the outpatient department in the Department of Pedodontics and Preventive Dentistry were selected who came for their first dental visit and were fulfilling the inclusion criteria. This study was performed under the Helsinki Declaration. Informed consent was obtained from the parents of all the children for the procedure of laser and conventional treatment.

\section{Inclusion Criteria}

- Children between 6 years and 12 years of age.

- The occurrence of at least two active occlusal caries extending in the dentine (D3 threshold, WHO system), without pulpal involvement in a primary or permanent molar.

- Absence of spontaneous pain.

- Absence of abscess, sinus, and fistula.

- Absence of developmental disorders.

- Absence of congenital or medical disorders.

- No previous laser/rotary (airotor) treatment of a carious lesion.

The present randomized controlled trial was aimed to make a fair comparison regarding pain perception and anxiety levels between laser cavity preparation and conventional airotor cavity preparation. The study was done using a split-mouth design, and the technique for cavity preparation to be employed first was randomized using the flip coin method.

\section{Treatment Procedure}

At the first dental visit, baseline pulse rate was recorded using a fingertip pulse oximeter (SCURE, MODEL NO. FTP 1000, India) during history taking and clinical examination in a calm and friendly environment. In the next appointment, cavity preparation was done with an Er,Cr:YSGG laser (BIOLASE Waterlase iPlus, USA) and conventional rotary (BEING FOSHAN HANDPIECE, China) method, using a split-mouth design. Pulse rate was measured after the completion of each cavity preparation and before commencing the restoration to correctly measure the stimulus-induced anxiety in the child. Patients were given a rest period between successive cavity preparation to reach the baseline pulse rate. For each treatment, the pain was also measured after the cavity preparation and before restoration by asking the child to indicate the face on the Wong-Baker Faces Pain Rating Scale. At the end, when the child had undergone both the procedures, the child was asked about the preference in-between laser and conventional rotary methods for future treatment of decayed teeth.

The data obtained were tabulated and subjected to statistical analysis. SPSS Software 20.0 was used for data analyzes.

\section{Results \\ Anxiety Level}

On comparison of the mean values of pulse rate before cavity preparation ( $85.57 \pm 10.523 /$ minute) and pulse rate after cavity preparation ( $93.2 \pm 9.654$ /minute) in the airotor group, the mean values of pulse rate after cavity preparation were higher with a mean difference of 7.633, and this difference was statistically significant with a $p$ value of $<0.001$. On comparison of the mean values of pulse rate before cavity preparation $(85.57 \pm 10.523 /$ minute), and pulse rate after cavity preparation $(89.57 \pm 12.085 /$ minute) in the laser group, the mean values of pulse rate after cavity preparation were higher with a mean difference of 4 , and it was statistically not significant with a $p$ value of 0.053 (Tables 1 and 2) and (Figs 1 and 2).

\section{Pain Perception}

On comparison of the mean values of pain during cavity preparation by airotor $(1.13 \pm 1.137)$ and laser $(0.87 \pm 1.137)$, the mean values of pain in the airotor group were higher with a mean difference of 0.267 ; however, it was statistically not significant with a $p$ value of 0.38 (Table 3) and (Fig. 3).

\section{Preference}

Out of 30 children, 13 (43\%) children prefer airotor and 17 (57\%) children prefer laser for future treatment of decayed teeth (Table 4) and (Fig. 4).

\section{Discussion}

In dental setup, pediatric patients recognize some stimuli that trigger their dental anxiety. Dental anxiety can be coped with by removing four major primary sensory triggers-sound (drilling), sight (air turbine drill), smell, and sensations (high-frequency vibrations). ${ }^{1-8}$

In the present study, pulse rate was found to be significantly higher after the cavity preparation with airotor when compared to the baseline pulse rate. However, no significant difference in pulse rate was observed before and after cavity preparation with the laser. The probable reason for airotor to cause more anxiety may be due to high-frequency sound and vibrations that are ineluctable with traditional rotary instruments that often make patients feel uncomfortable. The non-contact mode of erbium lasers with hard tissue produces less vibration in comparison to airotor permitting tooth preparations to be less anxiety-provoking and comfortable. There is no smell when cavity preparation is performed with adequate suction. Popping sound produced by the laser is more comfortable than the turbine noise. Through various studies, it has been found that fear of drill is a principal cause of dental anxiety among children. $1,9,15-18$

Evans et al. ${ }^{15}$ observed that children over 10 years of age chosen laser over the conventional method for cavity preparation. They concluded that this could be because less vibrations were produced by laser in comparison with the conventional method during cavity preparation. In another study conducted by Liu et al., ${ }^{16}$ it had been found that lower tooth vibration appeared in laser preparations, and that head or body movements were occasionally recorded during laser preparation, which suggests that a child's behavior can be greatly enhanced with laser cavity preparation. Similarly, Yamada et al. ${ }^{18}$ also found that the sound of the dental drill has the strongest influence on the unpleasant feeling of patients at the dental clinic. The result of the present study is also in accordance with the study conducted by Eren et al., ${ }^{9}$ who observed that patients were less anxious and more comfortable during cavity preparation with $\mathrm{Er}, \mathrm{Cr}$ :YSGG laser in comparison to airotor.

In the present study, the mean value of the pain associated with cavity preparation by airotor was found to be more than the cavities prepared by laser, although it was not statistically significant. Many studies have found significantly higher pain during cavity preparation with the airotor as compared to the laser. This can be due to variation in study design, use of different hard tissue lasers, 
Table 1: Comparison of pulse rate before and after cavity preparation in the airotor group

\begin{tabular}{|c|c|c|c|c|c|c|c|c|c|}
\hline & & \multirow[b]{2}{*}{$N$} & \multirow[b]{2}{*}{ Mean } & \multirow[b]{2}{*}{$\begin{array}{l}\text { Standard } \\
\text { deviation }\end{array}$} & \multicolumn{2}{|c|}{ Paired differences } & \multirow[b]{2}{*}{$t$} & \multirow[b]{2}{*}{$d f$} & \multirow[b]{2}{*}{$p$ value } \\
\hline & & & & & $\begin{array}{l}\text { Mean } \\
\text { difference }\end{array}$ & $\begin{array}{l}\text { Standard } \\
\text { deviation }\end{array}$ & & & \\
\hline \multirow[t]{2}{*}{$\begin{array}{l}\text { Airotor } \\
\text { group }\end{array}$} & $\begin{array}{l}\text { Pulse rate before cavity preparation } \\
\text { (during history taking/baseline) }\end{array}$ & 30 & 85.57 & 10.523 & -7.633 & 8.381 & -4.989 & 29 & $<0.001$ \\
\hline & Pulse rate after cavity preparation & 30 & 93.2 & 9.654 & & & & & \\
\hline
\end{tabular}

Table 2: Comparison of pulse rate before and after cavity preparation in the laser group

\begin{tabular}{|c|c|c|c|c|c|c|c|c|c|}
\hline & & \multirow[b]{2}{*}{$N$} & \multirow[b]{2}{*}{ Mean } & \multirow[b]{2}{*}{$\begin{array}{l}\text { Standard } \\
\text { deviation }\end{array}$} & \multicolumn{2}{|c|}{ Paired differences } & \multirow[b]{2}{*}{$t$} & \multirow[b]{2}{*}{$d f$} & \multirow[b]{2}{*}{$p$ value } \\
\hline & & & & & $\begin{array}{l}\text { Mean } \\
\text { difference }\end{array}$ & $\begin{array}{l}\text { Standard } \\
\text { deviation }\end{array}$ & & & \\
\hline \multirow[t]{2}{*}{ Laser group } & $\begin{array}{l}\text { Pulse rate before cavity } \\
\text { preparation (during history } \\
\text { taking/baseline) }\end{array}$ & 30 & 85.57 & 10.523 & -4 & 10.844 & -2.02 & 29 & 0.053 \\
\hline & $\begin{array}{l}\text { Pulse rate after cavity prepa- } \\
\text { ration }\end{array}$ & 30 & 89.57 & 12.085 & & & & & \\
\hline
\end{tabular}

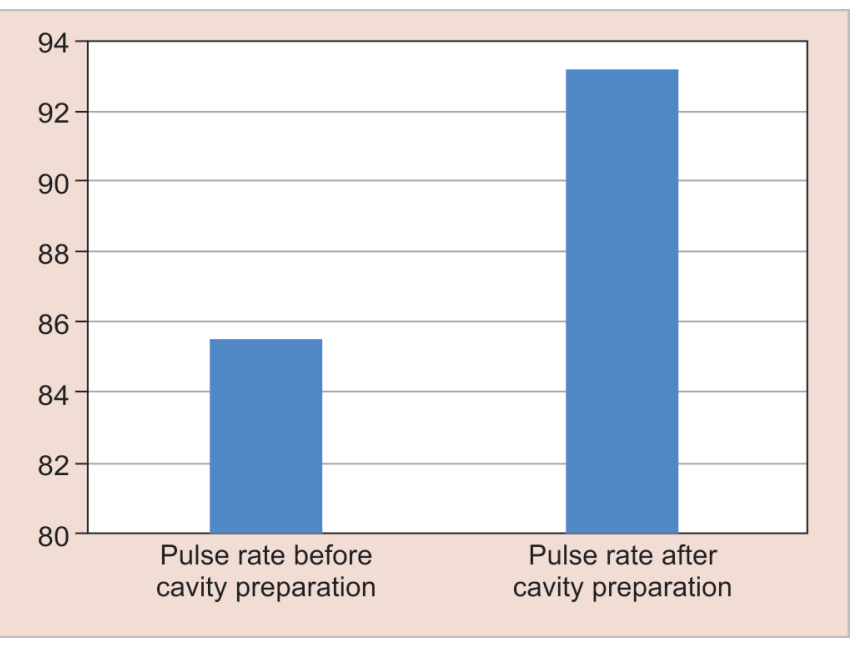

Fig. 1: Comparison of pulse rate before and after cavity preparation in the airotor group

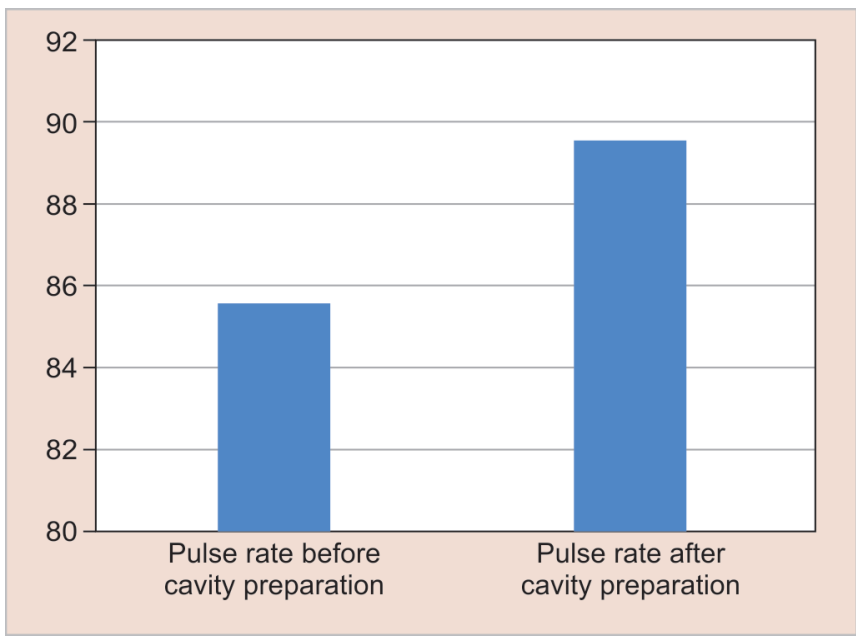

Fig. 2: Comparison of pulse rate before and after cavity preparation in the laser group

Table 3: Comparison of pain during cavity preparation in between airotor and laser groups

\begin{tabular}{|c|c|c|c|c|c|c|c|c|c|}
\hline & & \multirow[b]{2}{*}{$N$} & \multirow[b]{2}{*}{ Mean } & \multirow[b]{2}{*}{$\begin{array}{l}\text { Standard } \\
\text { deviation }\end{array}$} & \multicolumn{2}{|c|}{ Paired differences } & \multirow[b]{2}{*}{$t$} & \multirow[b]{2}{*}{$d f$} & \multirow[b]{2}{*}{$p$ value } \\
\hline & & & & & $\begin{array}{l}\text { Mean } \\
\text { difference }\end{array}$ & $\begin{array}{l}\text { Standard } \\
\text { deviation }\end{array}$ & & & \\
\hline \multirow[t]{2}{*}{ Pain } & Airotor group & 30 & 1.13 & 1.137 & 0.267 & 1.639 & 0.891 & 29 & 0.38 \\
\hline & Laser group & 30 & 0.87 & 1.137 & & & & & \\
\hline
\end{tabular}

and different age groups of the study subjects. The probable reason for the airotor to cause more pain may be the mechanism of tooth preparation. Cavity preparation from the airotor is by abrasion method that causes heat generation leading to a rise in intrapulpal temperature. Second, the pressure is applied to contact the rotating tool with the tooth surface. Thermal injury to the pulp caused by mechanical preparation results in neurogenic inflammation, giving rise to pain, and a hyperemic increase in pulpal blood flow. Whereas, $\mathrm{Er}, \mathrm{Cr}: Y S G G$ laser uses extremely short pulse durations that can easily ablate layers of calcified tissue with minimal thermal effect. It has a high empathy for hydroxyapatite and the highest absorption of water compared to other dental laser wavelengths. Erbium lasers have low penetration which causes minimal deleterious changes on the tooth and also results in a low perception of pain by the patient. Similar results were reported by Glockner et al., who demonstrated that there was a temperature drop in the pulp during cavity preparation with a laser due to cooling by water and air, while there was a rise in temperature to $>60^{\circ} \mathrm{C}$ with the conventional bur preparation. A higher temperature rise in the pulp leads to greater inflammation and more pain., ${ }^{9,10,19-27}$

In our study, when children were asked for the preference in-between laser and airotor for future treatment of decayed teeth, the majority of the children preferred laser over airotor. Almost all the studies which have compared laser with rotary instruments, as 


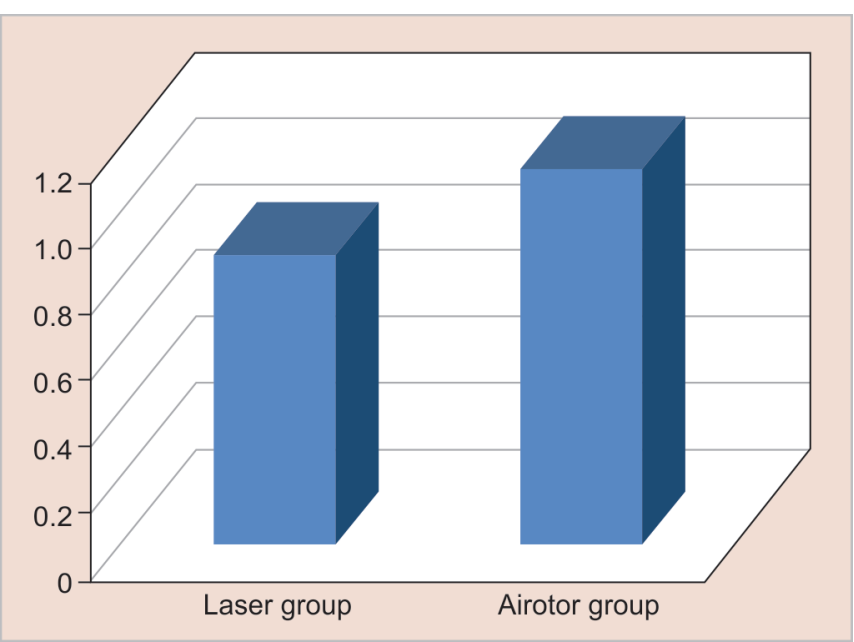

Fig. 3: Comparison of pain during cavity preparation in between airotor and laser groups

Table 4: Preference in between airotor and laser groups

\begin{tabular}{llc}
\hline & Preference $(N)$ & Valid percent \\
\hline Airotor & 13 & 43.3 \\
Laser & 17 & 56.7 \\
Total & 30 & 100 \\
\hline
\end{tabular}

a tool for cavity preparation have found similar results in favor of laser, which has led to the acceptance of laser. $13,15,19$

Genovese and Olivi ${ }^{19}$ evaluated the laser therapy efficacy in pediatric dentistry and found the acceptance was $90 \%$ for children needing hard-tissue treatments. In another study by Polizeli et al., ${ }^{13}$ it was found that children's preference for laser as the method of selective caries removal in a future restorative treatment was $90 \%$.

In the present study as well as in the previous studies, promising results are obtained when lasers are used for cavity preparation in alleviating anxiety and pain. But, despite encouraging results, the applicability of lasers in current clinical practice is uncertain. Lasers represent an advanced technological device that is expected to be much more expensive than traditional drills for dental treatments, which could influence its use in daily clinical practice. Since different wavelengths are necessary for various soft and hard tissue procedures, the practitioner may need more than one laser. High startup costs are required to purchase the equipment, implement the technology, and invest in the required education and training. ${ }^{28-30}$

However, laser use could be justifiable in certain circumstances, such as, in children showing high dental anxiety. The laser can be a good alternative for anxiety or patients with a phobia, but more studies have to be done for that to be well established.

\section{Conclusion}

During cavity preparation, Er,Cr:YSGG laser can be more effective, when compared with rotary instruments, in reducing pain and anxiety in children. Thus, Er,Cr:YSGG laser application can be a suitable alternative for restorative treatment in pediatric dentistry.

\section{Clinical Significance}

$\mathrm{Er}, \mathrm{Cr}: Y S G G$ laser helps the children to remain calm during the cavity preparation.

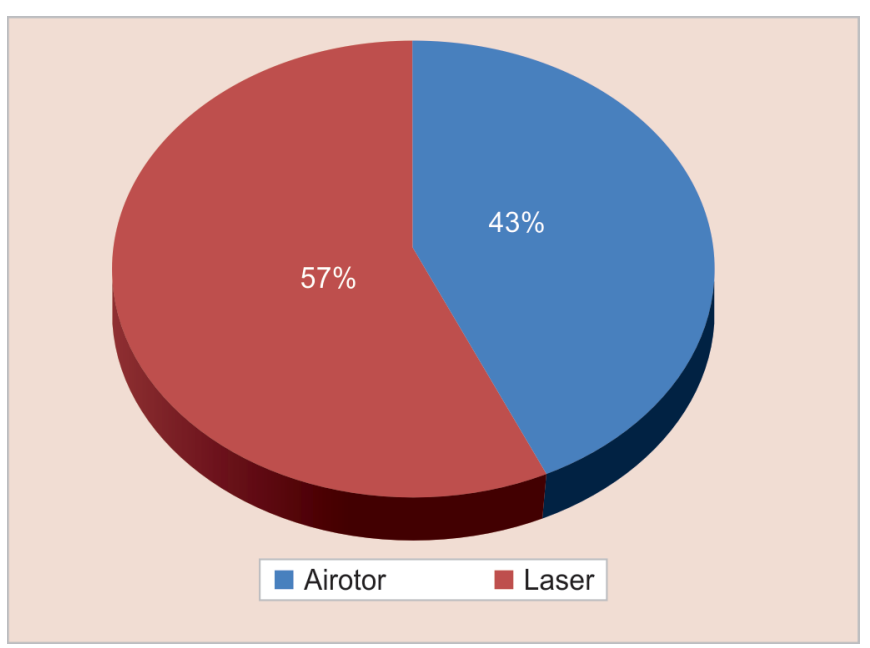

Fig. 4: Preference in between airotor and laser

\section{References}

1. Belcheva A, Shindova M. Subjective acceptance of pediatric patients during cavity preparation with Er:YAG laser and conventional rotary instruments. J IMAB 2014;20(5):631-633. DOI: 10.5272/ jimab.2014205.631.

2. Hmud R, Walsh LJ. Dental anxiety: causes, complications and management approaches. J Minim Interv Dent 2009;2(1):67-783.

3. Kleinknecht RA, Klepac RK, Alexander LD. Origins and characteristics of fear of dentistry. J Am Dent Assoc 1973;86(4):842-848. DOI: 10.14219/jada.archive.1973.0165.

4. Armfield JM. Towards a better understanding of dental anxiety and fear: cognitions vs. experiences. Eur J Oral Sci 2010;118(3):259-264. DOI: 10.1111/j.1600-0722.2010.00740.x.

5. Eitner S, Wichmann M, Paulsen A, et al. Dental anxiety-an epidemiological study on its clinical correlation and effects on oral health. J Oral Rehabil 2006;33(8):588-593. DOI: 10.1111/j.13652842.2005.01589.x.

6. Cohen SM, Fiske J, Newton JT. The impact of dental anxiety on daily living. Br Dent J 2000;189(7):385-390. DOI: 10.1038/sj.bdj.4800777.

7. Raj $\mathrm{S}$, Agarwai $\mathrm{M}$, Aradya $\mathrm{K}$, et al. Evaluation of dental fear in children during dental visit using children's fear survey schedule-dental subscale. Int J Clin Pediatr Dent 2013;6(1):12-15. DOI: 10.5005/ jp-journals-10005-1178.

8. Walsh LJ. Anxiety prevention: implementing the $4 \mathrm{~S}$ principle in conservative dentistry. Auxilliary 2007;17(5):24-26.

9. Eren $F$, Altinok B, Ertugral $F$, et al. The effect of erbium, chromium: yttrium-scandium-gallium-garnet (Er,Cr:YSGG) laser therapy on pain during cavity preparation in pediatric dental patients: a pilot study. Oral Health Dent Manag 2013;12(2):80-84.

10. Visuri SR, Walsh JT, Wigdor HA. Erbium laser ablation of dental hard tissue: effect of water cooling. Lasers Surg Med 1996;18(3):294-300. DOI: 10.1002/(SICI)1096-9101(1996)18:3<294::AID-LSM11>3. $0 . \mathrm{CO} ; 2-6$.

11. Zhegova GG, Rashkova MR. Er-YAG laser and dental caries treatment of permanent teeth in childhood. J of IMAB 2015;21(1):699-704. DOI: 10.5272/jimab.2015211.699.

12. Boj J, Galofre N, Espana A, et al. Pain perception in pediatric patients undergoing laser treatments. J Oral Laser Applications 2005;5:85-89.

13. Polizeli SAP, Valério RA, Nemezio MA, et al. Sensitivity evaluation of caries removal in primary molars using an Er:YAG laser: a randomized split-mouth clinical trial. Eur J Pharm Med Res 2016;3(8):116-122.

14. Tiwari N, Tiwari S, Thakur R, et al. Evaluation of treatment related fear using a newly developed fear scale for children: "fear assessment picture scale" and its association with physiological response. Contemp Clin Dent 2015;6(3):327-331. DOI: 10.4103/0976-237X. 161871. 
15. Evans D, Matthews S, Pitts N, et al. A clinical evaluation of an Erbium:YAG laser for dental cavity preparation. Br Dent J 2000;188(12):677-679. DOI: 10.1038/sj.bdj.4800575.

16. Liu JF, Lai YL, Shu WY, et al. Acceptance and efficiency of Er:YAG laser for cavity preparation in children. Photomed Laser Surg 2006;24(4):489-493. DOI: 10.1089/pho.2006.24.489.

17. Santos $C R$, Tonetto $M R$, Presoto $C D$, et al. Application of Er:YAG and $\mathrm{Er}, \mathrm{Cr}: Y S G G$ lasers in cavity preparation for dental tissues: a literature review. World J Dent 2012;3(4):340-343.

18. Yamada T, Ebisu S, Kuwano S. A questionnaire survey on the effect of the sound of dental drills on the feeling of patients in dental clinics. J Acoust Sci Tech 2006;27(5):305-308. DOI: 10.1250/ast. 27.305.

19. Genovese MD, Olivi G. Laser in pediatric dentistry: patient acceptance of hard and soft tissues therapy. Eur J Paediatr Dent 2008;9(1):13-17.

20. Matsumoto $\mathrm{K}$, Hossain M, Hossain MMI, et al. Clinical assessment of Er,Cr:YSGG laser application for cavity preparation. J Clin Laser Med Surg 2002;20(1):17-21. DOI: 10.1089/104454702753474968.

21. Hadley J, Young D, Eversole L, et al. A laser- powered hydrokinetic system for caries removal and cavity preparation. J Am Dent Assoc 2000;131(6):777-785. DOI: 10.14219/jada.archive.2000.0277.

22. Lin S, Caputo A, Eversole L, et al. Topographical characteristics and shear bond strength of tooth surfaces cut with a laser-powered hydrokinetic system. J Prosthet Dentist 1999;82(4):451-455. DOI: 10.1016/S0022-3913(99)70033-8.
23. Bohari RM, Chunawalla YK, Ahmed BMN. Clinical evaluation of caries removal in primary teeth using conventional, chemicomechanical and laser technique: an in vivo study. J Contemp Dent Pract 2012;13(1):40-47. DOI: 10.5005/jp-journals-10024-1093.

24. Glockner K, Rumpler J, Ebeleseder K, et al. Intrapulpal temperature during preparation with the Er:YAG laser compared to the conventional burr: an in vitro study. J Clin Laser Med Surg 1998;16(3):153-157. DOI: 10.1089/clm.1998.16.153.

25. De Moor RJ, Delm KI. Laser-assisted cavity preparation and adhesion to erbium-lased tooth structure: Part 1. Laser-assisted cavity preparation. J Adhes Dent 2009;11:427-438.

26. De Moor RJ, Delme KI. Laser-assisted cavity preparation and adhesion to erbium-lased tooth structure: Part 2. Present-day adhesion to erbium-lased tooth structure in permanent teeth. J Adhes Dent 2010;12:91-102.

27. Delmé $K$, Meire $M$, De Bruyne $M$, et al. Cavity preparation using an Er:YAG laser in the adult dentition. Rev Belge Med Dent 2009;64:7180.

28. Coluzzi DJ. Lasers in dentistry. Compend Contin Educ Dent 2005;26(6A Suppl):429-435.

29. Olivi G, Genovese MD. Laser restorative dentistry in children and adolescents. Eur Arch Paediatr Dent 2011;12(2):68-78. DOI: 10.1007/ BF03262782.

30. van AG. Erbium lasers in dentistry. Dent Clin North Am 2004;48(4):10171059. DOI: 10.1016/j.cden.2004.06.001. 